\title{
HIGH SCHOOL OF ARCHITECTURE, ART AND DESIGN WITH A POST MODERN ARCHITECTURAL APPROACH SEKOLAH TINGGI ARSITEKTUR, SENI DAN DESAIN DENGAN PENDEKATAN ARSITEKTUR POST MODERN
}

\author{
Gilang Sanusi Haryanto ${ }^{1)}$, Anityas Dian Susanti ${ }^{2)}$, Gatoet Wardianto ${ }^{3)}$ \\ Program Studi Arsitektur, Fakultas Teknik, Universitas Pandanaran \\ sesajen03@ gmail.com ${ }^{1)}$ \\ tyas@unpand.ac.id ${ }^{2)}$ \\ gatoetwardianto@yahoo.com ${ }^{3)}$
}

\begin{abstract}
Abstrak
Pada umumnya orang mengenal dengan sebutan sekolah seni pasti tertuju di Institut Seni Indonesia di Surakarta atau Institut Seni Indonesia di Yogyakarta, yang merupakan sebuah kebanggaan tersendiri bagi kota Semarang khususnya para lulusan SLTA memiliki sekolah tinggi arsitektur, seni dan desain yang berada di kota Semarang ini. Tujuan dalam perencanaan dan perancangan ini adalah menghasilkan konsep perencanaan dan perancangan sekolah tinggi arsitektur, seni dan desain yang dapat menjadi wadah untuk kegiatan pendidikan, belajar mengajar, untuk para mahasiswa dan pengajar. Site untuk perencanaan sekolah berada di Jalan Raya Ngaliyan, Ngaliyan, Semarang. Metode perancangan menggunakan pendekatan aspek kontekstual, aspek fungsional, aspek kinerja, aspek teknis Perancangan sekolah ini menggunakan pendekatan arsitektur post modern, yang tujuan post modern adalah memberikan kesempatan pada bangunan untuk dapat di ekspresikan dalam berbagai hal. Yang pada dasarnya fasade dan gubahan massa bangunan tersebut bebas berekspresi sehingga bisa membentukan bentukan massa yang tak beraturan.

Kata kunci: Sekolah, Arsitektur, Seni, Desain, Post Modern.
\end{abstract}

\begin{abstract}
In general, people who know as an art school are sure to focus on the Indonesian Art Institute in Surakarta or the Indonesian Art Institute in Yogyakarta, which is a matter of pride for the city of Semarang, especially high school graduates who have a high school of architecture, art and design located in the city of Semarang. The purpose of this planning and design is to produce a planning and design concept for a high school of architecture, art and design that can become a forum for educational activities, teaching and learning, for students and teachers. The site for school planning is on Jalan Raya Ngaliyan, Ngaliyan, Semarang. The criteria for school planning are that around the site there are supporting facilities in the form of commercial and residential buildings, the site environment is not too noisy and suitable for teaching and learning activities and the location of the site is very strategic and easy to reach and pass by public or private vehicles. With the existence of a high school of architecture, art and design in Semarang, it is hoped that it can produce graduate students with prospects for the world of work in the architectural field (expert in building architecture, landscape architecture expert, and expert in feasibility studies), art (painting, and professional fine arts). and design (including: visual communication, interior and product design), as well as participating in socializing the art life in Semarang.

Keywords: School, Architecture, Art, Design, Post Modern.
\end{abstract}

\section{PENDAhULUAN}

Sekolah tinggi merupakan perguruan tinggi yang menyelenggarakan pendidikan akademik, pendidikan vokasi, dan pendidikan profesi dalam sejumlah ilmu pengetahuan, teknologi, dan seni. Sekolah tinggi hanya menyelenggarakan pendidikan dengan satu fakultas yang terbagi ke dalam berbagai jurusan.

Arsitektur sendiri merupakan ilmu dan seni dalam mendesain dan merancang bangunan dan struktur. Pada intinya, Arsitektur bertujuan untuk menciptakan sebuah ruang untuk kebutuhan manusia. 
Seni didefinisikan sebagai ekspresi atau penerapan keterampilan kreatif manusia, terutama dalam bentuk visual.

Desain Komunikasi Visual (DKV) adalah cabang ilmu desain yang mempelajari konsep komunikasi dan ungkapan kreatif, teknik dan media dengan memanfaatkan elemen-elemen visual ataupun rupa untuk menyampaikan pesan untuk tujuan tertentu.

\section{Tujuan}

Menghasilkan konsep perencanaan dan perancangan sekolah tinggi arsitektur, seni dan desain yang dapat menjadi wadah untuk kegiatan pendidikan, belajar mengajar, untuk para mahasiswa dan pengajar.

\section{Manfaat}

Dapat bermanfaat sebagai masukan dan pengetahuan bagi mahasiswa yang akan menempuh tugas akhir, selain itu dapat digunakan sebagai masukan bagi Pemerintah Daerah Kota Semarang dan pihak-pihak yang berkepentingan pada pengembangan daerah tersebut.

\subsection{Preseden}

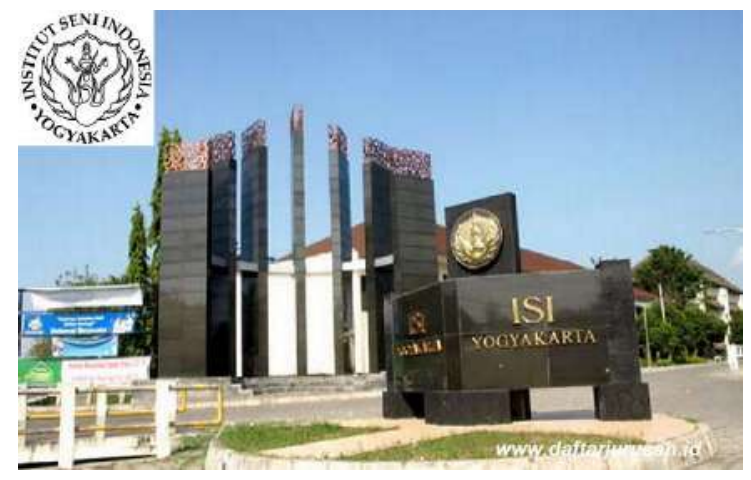

Gambar 1. Tampak Pintu Masuk ISI Yogya

Nama Bangunan Institut Seni Indonesia Yogyakarta

$\begin{array}{ll}\text { Luas } & : 18 \text { hektar } \\ \text { Alamat } & \text { : Panggungharjo, Sewon, } \\ & \text { Bantul } \\ \text { Arsitek } & : \text { Dibentuk atas dasar } \\ & \text { Keputusan Presiden RI No. } \\ & 39 / 1984 \text { tanggal 30 Mei 1984 } \\ \text { Fungsi } & : \text { Kampus, Pusat Pendidikan } \\ & \text { Sekolah Seni }\end{array}$

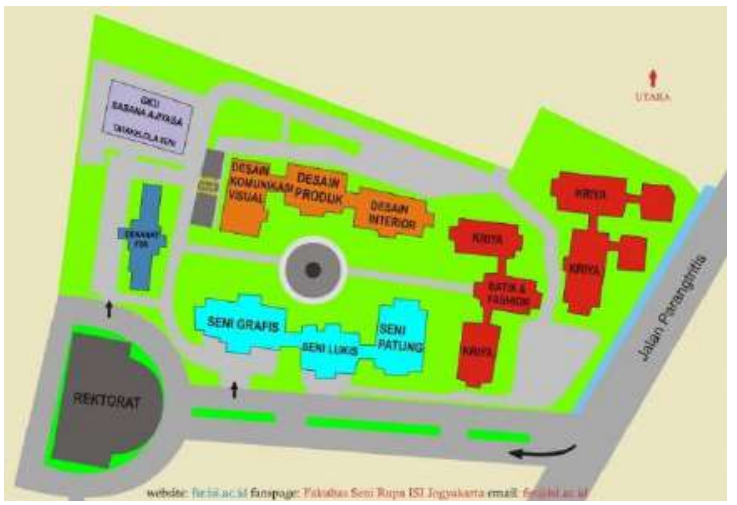

Gambar 2. Site Plan

Kampus ISI Yogyakarta terletak di Jalan Parangtritis Km. 6, Desa Panggungharjo, Kecamatan Sewon, Kabupaten Kabupaten Bantul, Daerah Istimewa Yogyakarta. Institut ini mengkhususkan pada pendidikan di bidang seni, yang terkelompok ke dalam tiga fakultas, yakni Fakultas Seni Rupa, Fakultas Seni Pertunjukan, dan Fakultas Seni Media Rekam. ISI Yogyakarta dibentuk berdasarkan penggabungan atas tiga pendidikan tinggi seni yang sudah ada sebelumnya yaitu yaitu Sekolah Tinggi Seni Rupa Indonesia "ASRI", Akademi Musik Indonesia "AMI", dan Akademi Seni Tari Indonesia "ASTI". (Wikipedia : 7 Juni 2020)

ISI Yogyakarta terdiri atas 3 fakultas yaitu fakultas seni pertunjukan, seni rupa, dan seni media rekam.

a. Fakultas Seni Pertunjukan

Misi Menyelenggarakan pendidikan tinggi seni pertunjukan yang berkualitas untuk mengedepankan pelestarian, pengelolaan, dan pengembangan potensi seni, serta budaya dan kearifan lokal nusantara yang berdaya saing dalam percaturan global.

Fakultas Seni Pertunjukan terbagi lagi menjadi beberapa bagian yaitu :

- Tari

- Karawitan

- Musik

- Teater

- Etnomusikologi

- Pedalangan

b. Fakultas Seni Rupa 
Misi Menyelenggarakan pendidikan bidang ilmu seni rupa yang di dalamnya merupakan unsur-unsur yang mempunyai kekhasan pada konsep, fungsi, terapan, motivasi penciptaan, bentuk, maupun material dan tekniknya dari selurung cabang seni rupa yang tumbuh dari pohon ilmu seni.

Fakultas Seni Rupa terbagi lagi menjadi beberapa bagian yaitu :

- Seni Murni

- Kriya

- Batik dan Fashion

- Desain Interior

- Desain Komunikasi Visual

- Desain Produk

\section{c. Fakultas Seni Media Rekam}

Misi Menyelenggarakan pendidikan yang memadukan kualitas intelektual dan kepekaan estetik yang disinergikan dengan kecanggihan teknologi rekam untuk menghasilkan insan yang kreatif dan berkepribadian yang menjunjung jati diri bangsa.

Fakultas Seni Rupa terbagi lagi menjadi beberapa bagian yaitu :

- Film dan Televisi

- Fotografi

- Animasi

\subsection{Kesimpulan Preseden}

Jadi kesimpulan yang saya ambil dari beberapa preseden diatas bahwa perancangan desain yang akan saya rancang ini, dengan membuat sekolah tinggi arsitektur, seni dan desain seperti dengan preseden ISI Yogyakarta. ISI Yogyakarta adalah Institut seni, yang belum ada fakultas arsitekturnya. Maka dari itu dalam perancangan ini saya membuat 3 fakultas yaitu fakultas arsitektur, fakultas seni dan fakultas desain.

Dan studi fakultas apa yang akan saya terapkan adalah sebagai berikut :

1. Fakultas Arsitektur

Visi Fakultas Arsitektur menyelenggarakan program Pendidikan arsitektur yang inovatif, mandiri, berbasis kearifan lokal dan mitigasi bencana

2. Fakultas Seni

Visi Menjadi Fakultas Seni yang handal di Indonesia, mempunyai standar internasional dalam keilmuannya, dengan tetap memperhatikan tradisi dan kearifan lokal dalam mengembangkan seni, disain, ilmu pengetahuan dan teknologi, guna meningkatkan kualitas hidup dan peradaban.

3. Fakultas Disain

Visi Menjadi pusat unggulan pendidikan, riset dan pengembangan desain komunikasi visual di Indonesia.

\section{TINJAUAN TEORI}

Arsitektur Post Modern adalah arsitektur yang menyatukan antara Art dan Science, Craft dan Technology Internasional dan lokal yang merupakan hasil perkembangan sumber daya manusia terhadap arsitektur modern. Post modern dalam arsitektur memiliki tujuan untuk menyelesaikan permasalahan pada arsitektur modern yang dianggap tidak memiliki makna terhadap konteks, membuka kemungkinan yang ambigu terhadap persepsi ruang, memecahkan persepsi-persepsi dan bersatu dengan berbagai arsitek untuk membuka prinsip baru yang lebih berkelanjutan.

Tujuan post modern adalah memberikan kesempatan pada bangunan untuk dapat di ekspresikan dalam berbagai bentuk. Yang pada fasade dan gubahan massa bangunan tersebut bebas berekspresi bentuk tak beraturan .

\section{METODOLOGI PERANCANGAN}

\section{- Pendekatan aspek kontekstual}

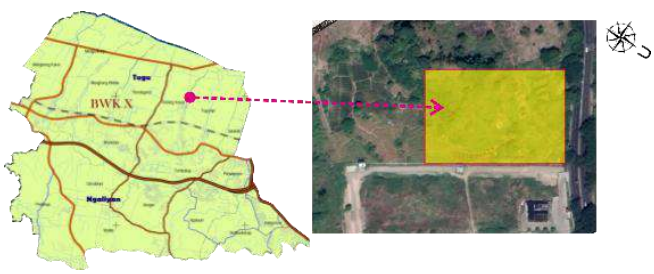

Gambar 3. Tapak Terpilih

Lokasi tapak terletak di Jalan Raya Ngaliyan, Ngaliyan, Semarang. Dengan 
kondisi tapak menghadap kearah barat. Tapak ini memiliki luas $\pm 45.000 \mathrm{~m}^{2}$, adapun batas-batasnya adalah :

$\begin{array}{ll}\text { Timur Laut } & \text { : Pizza Hut Ngaliyan } \\ & \text { dan McDonald's } \\ & \text { Ngaliyan } \\ \text { Tenggara } & \text { : Lahan Kosong } \\ \text { Barat Daya } & \text { : Lahan Kosong } \\ \text { Barat Laut } & \text { : Jalan Raya Ngaliyan }\end{array}$

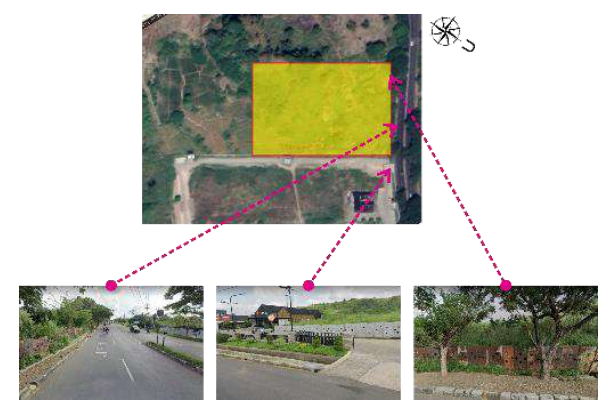

Gambar 4. View Sekitar Tapak

Dari kriteria site diatas maka site yang dipilih adalah :

- Site terletak di Jalan Raya Ngaliyan, Ngaliyan, Semarang.

- Terdapat sarana pendukung berupa bangunan komersial dan permukiman.

- Dekat dengan kampus besar yaitu kampus UIN Walisongo.

- Sekitar lingkungan site, banyak terdapat tempat kos untuk mahasiswa.

- Lingkungan site tidak terlalu bising dan cocok untuk kegiatan belajar-mengajar.

- Letak site sangat strategis mudah dicapai dan dilewati oleh kendaraan umum ataupun pribadi.

- Kondisi jalan yang baik, tidak berlubang/banyak kerusakan.

- Jalan Raya Ngaliyan sebagai jalan utama dengan lebar jalan \pm 20 meter dengan jalan dua lajur.

\section{- Pendekatan aspek fungsional}

Para pelaku kegiatan yang akan berada dalam fasilitas sekolah tinggi ini terdiri menjadi beberapa kelompok yang dibagi berdasarkan jenis kegiatannya diantara lain sebagai berikut :
Tabel 1. Aktivitas

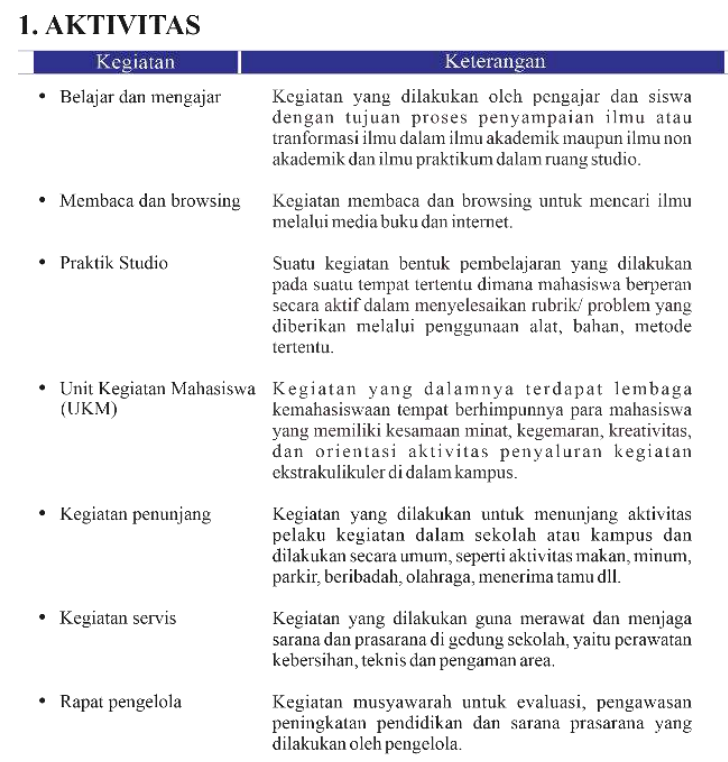

Kebutuhan ruang sangat beragam sesuai dengan pelaku aktivitas. Penjelasan mengenai analisis kebutuhan ruang dijabarkan melalui pelaku, aktivitas, kebutuhan ruang yang akan dijelaskan melalui tabel berikut :

Tabel 2. Kebutuhan Ruang

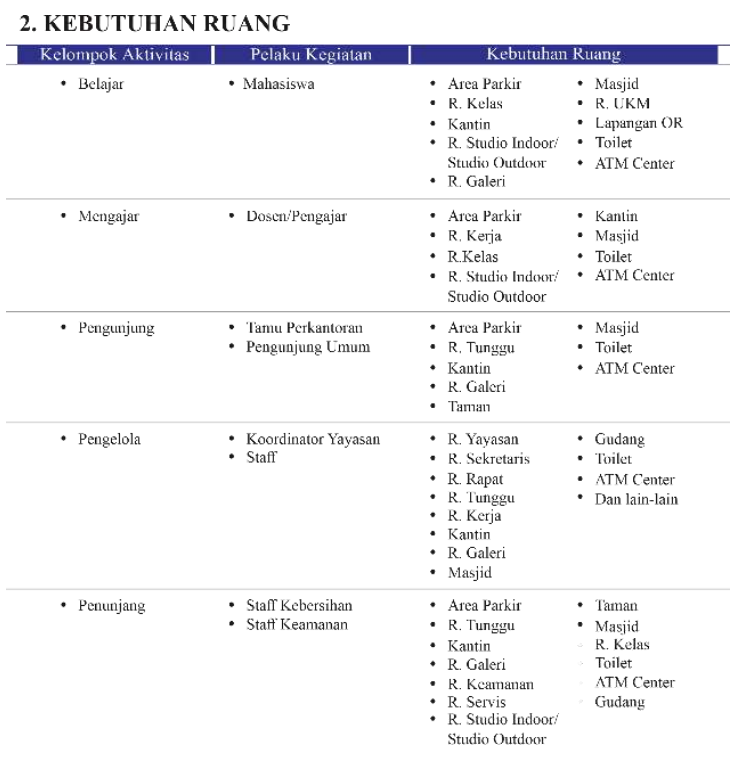




\section{- Pendekatan aspek kinerja}

a.Pencahayaan

Pencahayaan menggunakan pencahayaan alami melalui bukaan bukaan pada bangunan serta penerangan buatan dengan listrik yang bersumber dari PLN.

b.Penghawaan

Penghawaan menggunakan sistem pengkondisian udara alami berupa bukaan di dinding dan pertimbangan khusus untuk ruangan yang membutuhkan pengkondisian udara buatan, yaitu AC split wall-central.

c. Jaringan listrik

Untuk menunjang sistem bangunan seoptimal mungkin dengan pemanfaatan listrik dari PLN serta genset dan panel surya sebagai sumber energi cadangan untuk mensuplai kebutuhan listrik.

d.Jaringan air bersih dan air kotor.

Untuk kebutuhan air bersih bersumber dari sumur bor. Distribusi air dari sumber air di pompa ke ground tank lalu didistribusikan ke tiap rooftank masing - masing gedung.

Sedangakan untuk air kotor dari saluran pembuangan - ke resapan terakhir menuju saluran lingkungan.

e. Sistem pemadam kebakaran

Untuk sistem penanganan apabila terjadi kebakaran pada bangunan ini yaitu menggunakan fire hydrant, spinkler, halon gas, fire damper, smoke and heating ventialating dan vent and exhaus.

f. Sistem transportasi vertikal

Sistem transportasi vertikal pada bangunan menggunakan tangga dan lift. Karna dari bangunan sendiri yang rata - rata 3 lantai dan lift juga berfungsi bagi penyandang disabilitas.

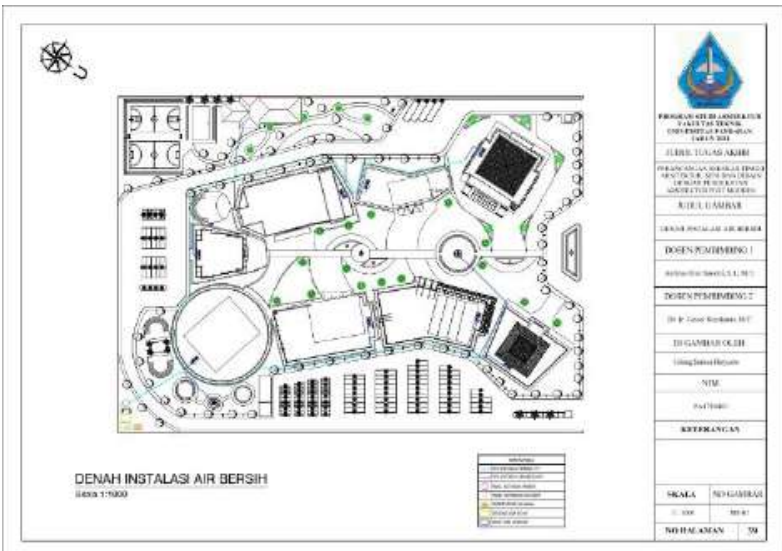

Gambar 5. Denah Instalasi Air Bersih

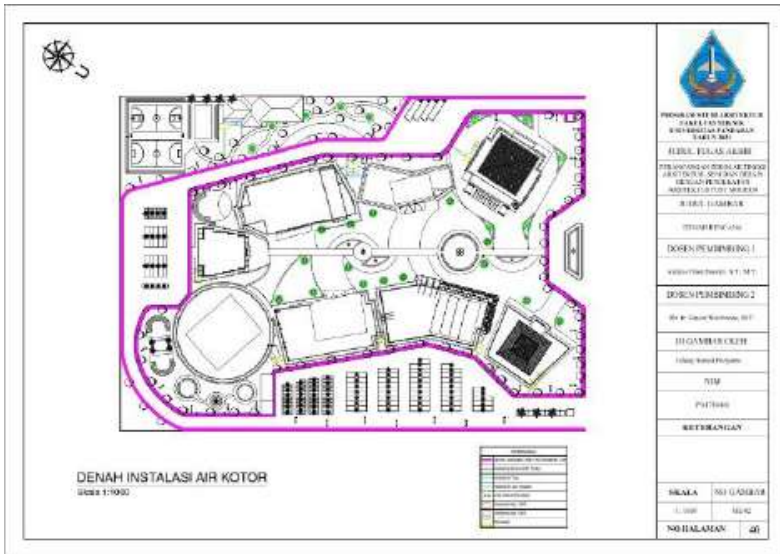

Gambar 6. Denah Instalasi Air Kotor

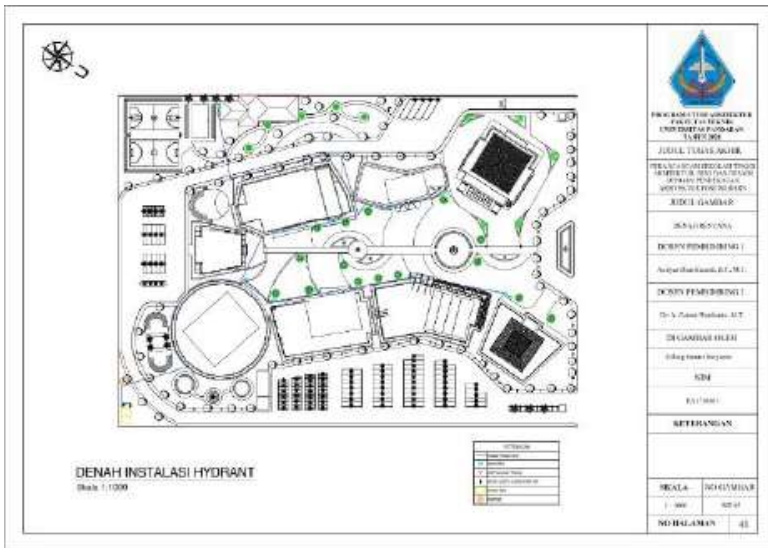

Gambar 7. Denah Instalasi Hydrant 


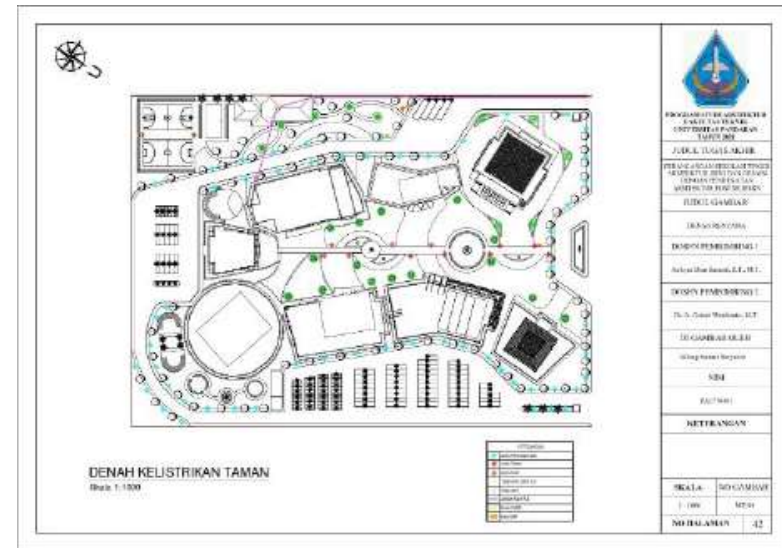

Gambar 8. Denah Kelistrikan Taman

\section{- Pendekatan aspek teknis}

a. Struktur Bawah

Jenis Pondasi yang digunakan pondasi pelat dan pondasi bored pile. Dipergunakan pada bangunan yang memiliki bentang lebar seperti fasilitas gedung pendidikan atau gedung fakultas, gedung serbaguna.

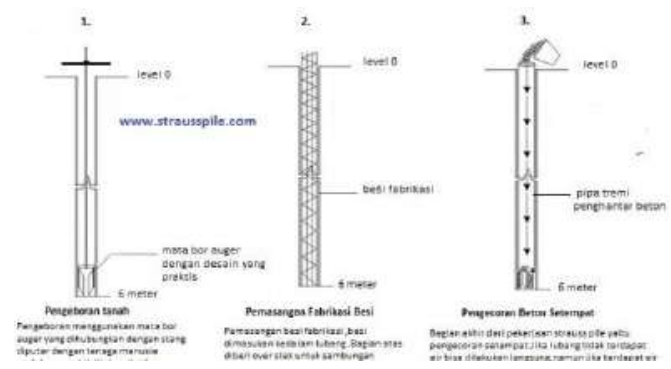

Gambar 9. Rencana Struktur Bawah Pondasi Bored Pile

\section{b. Struktur Atas (Kolom dan Balok)}

Pada struktur atas kolo dan balok menggunakan beton bertulang.

\section{c. Struktur Atap}

Struktur atap menggunakan atap datar dengan menggunakan pelat beton dan atap kerangka baja.

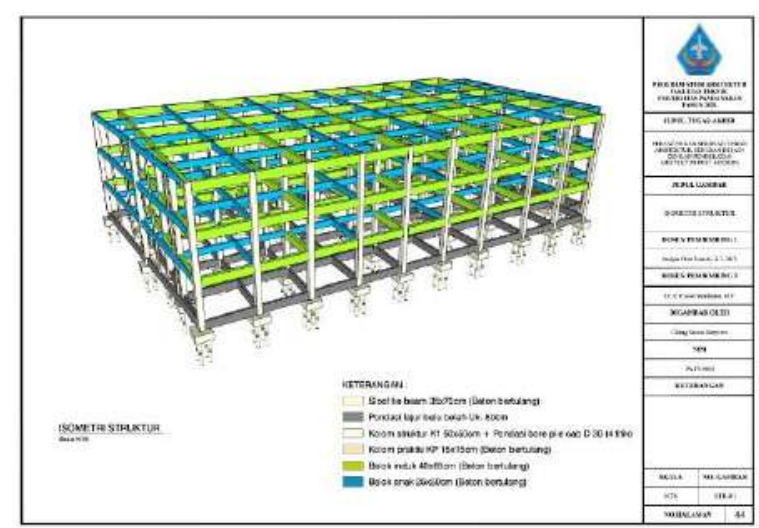

Gambar 10. Rencana Struktur Bangunan

\section{PEMBAHASAN}

Berdasarkan perhitungan besaran ruang pada bab sebelumnya, didapatkan luasan :

Tabel 4.1 Rekapitulasi

REKAPITULASI

\begin{tabular}{|c|l|r|}
\hline \hline No & \multicolumn{1}{|c|}{ KELOMPOK KEGIATAN } & \multicolumn{1}{c|}{ LUAS (M2) } \\
\hline 1 & RUANG KELOMPOK GEDUNG REKTORAT (3 LANTAI) & 770.22 \\
\hline 2 & RUANG KELOMPOK GEDUNG FAK. ARSITEKTUR (3 LANTAI) & $2,842.94$ \\
\hline 3 & RUANG KELOMPOK GEDUNG FAK. DESAIN (3 LANTAI) & $2,504.94$ \\
\hline 4 & RUANG KELOMPOK GEDUNG FAK. SENI (2 LANTAI) & $1,905.70$ \\
\hline 5 & RUANG KELOMPOK GEDUNG STUDIO (3 LANTAI) & $2,790.74$ \\
\hline 6 & RUANG KELOMPOK GEDUNG PENUNJANG (2 LANTAI) & 804.34 \\
\hline 7 & RUANG KELOMPOK GEDUNG SERBAGUNA (AUDITORIUM) & 991.43 \\
\hline 8 & RUANG KELOMPOK GEDUNG MASJID & 881.45 \\
\hline 9 & RUANG KELOMPOK GEDUNG SERVIS & 190.84 \\
\hline 10 & RUANG KELOMPOK LAPANGAN OLAH RAGA & $1,300.05$ \\
\hline 11 & RUANG KELOMPOK KIOS RETAIL DAN ATM CENTER & 63.05 \\
\hline 12 & RUANG KELOMPOK PARKIRAN & $7,176.00$ \\
\hline & Luas Total Bangunan (m2) & $\mathbf{2 2 , 2 2 1 . 7 1}$ \\
\hline & Dibulatkan (m2) & $\mathbf{2 2 , 2 0 0 . 0 0}$ \\
\hline
\end{tabular}

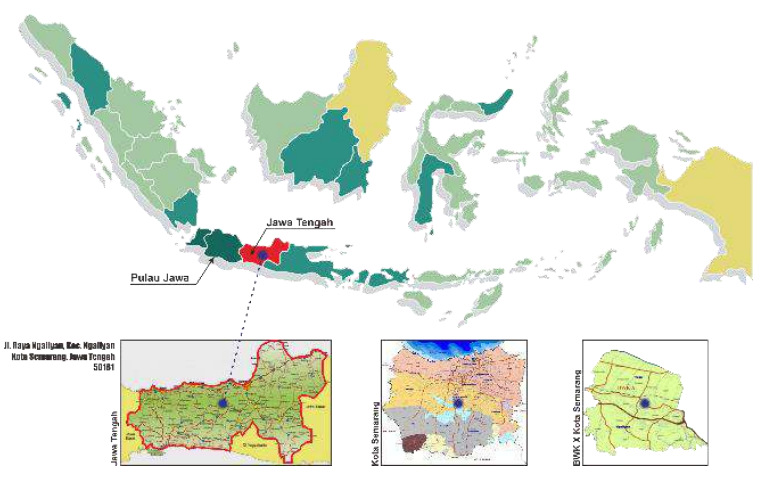

Gambar 11. Lokasi Site 
Peraturan RTRW di BWK X sebagai berikut :

Dengan Luas Lahan : $45.000 \mathrm{~m}^{2}$

GSB : $20 \mathrm{~m}$

$\mathrm{KDB}: 50 \%=22.500 \mathrm{~m}^{2}$

KLB : Max. 4 Lantai

$\mathrm{RTH}: 13.500 \mathrm{~m}^{2}$

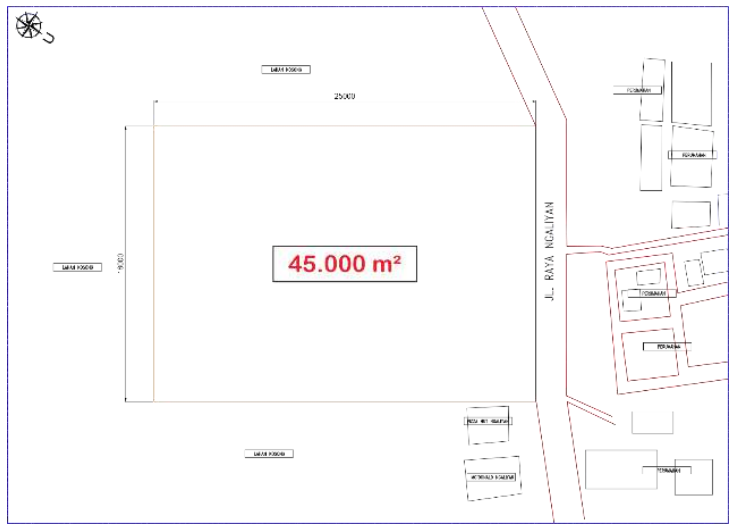

Gambar 12. Site Eksisting

Melihat potensi site yang terletak pada zona kawasan pengembangan pendidikan serta kriteria lokasi yang baik untuk pendidikan yaitu kondisi infrastruktur yang baik, pencapaian ke site dengan mudah, dan yang penting kondisi lingkungan yang tenang dan nyaman untuk proses kegiatan belajar mengajar karna site berdekatan dengan perumahan, dan site tidak terlalu ramai/bising, serta site bagian belakang dan samping masih lahan kosong dan bangunan tidak banyak, jadi lebih baik untuk kegiatan belajar menjadi tenang dan kondusif.

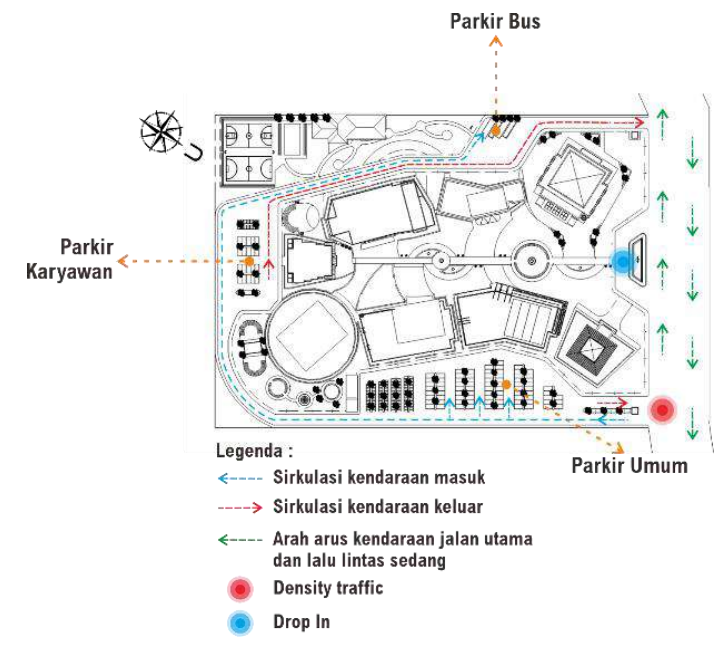

Gambar 13. Analisa Aksebilitas

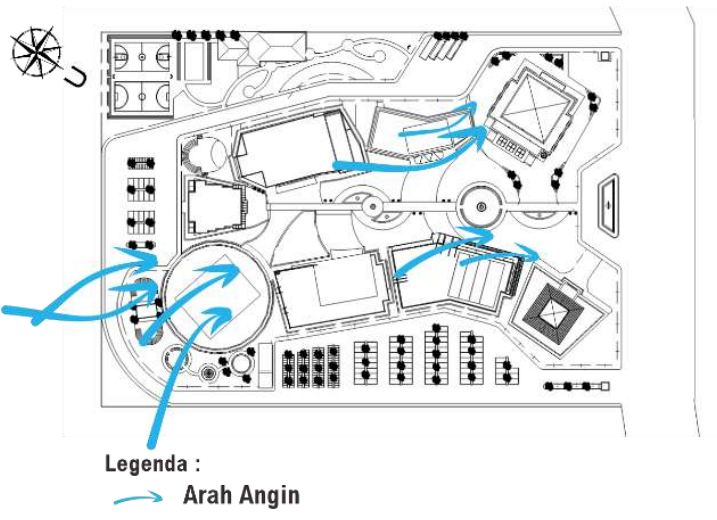

Gambar 14. Analisa Angin

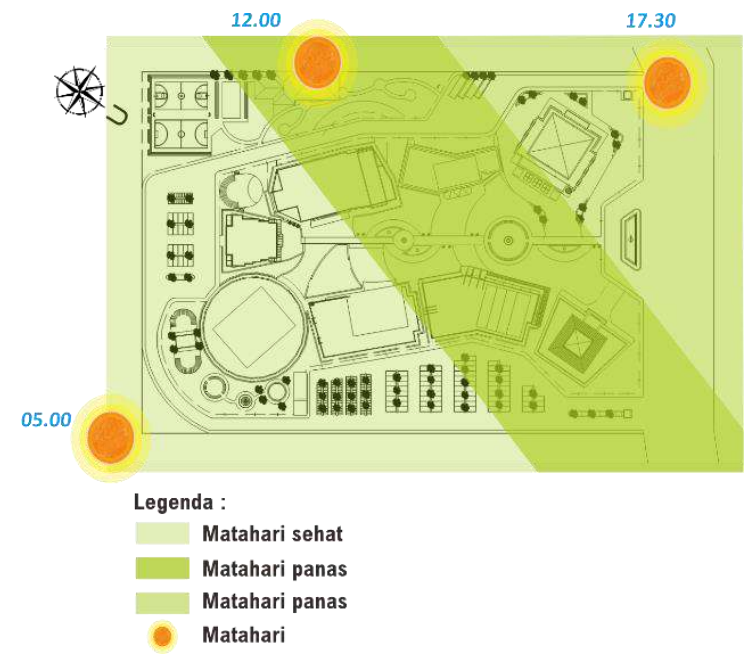

Gambar 15. Analisa Matahari

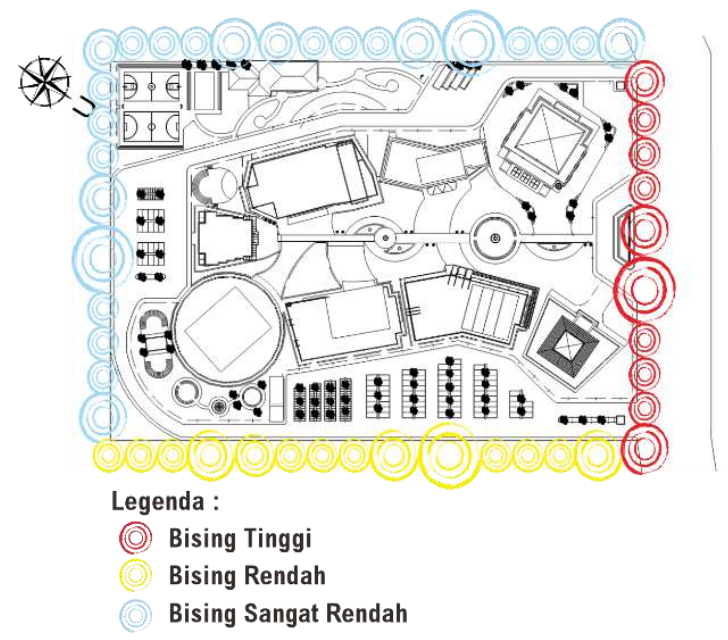


segitiga, jajar genjang, trapesium. Sehingga membentuk pola massa yang tak beraturan.

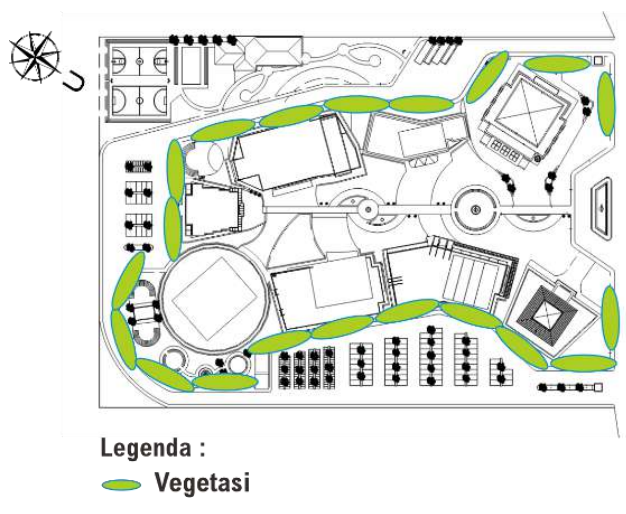

Gambar 17. Analisa Vegetasi

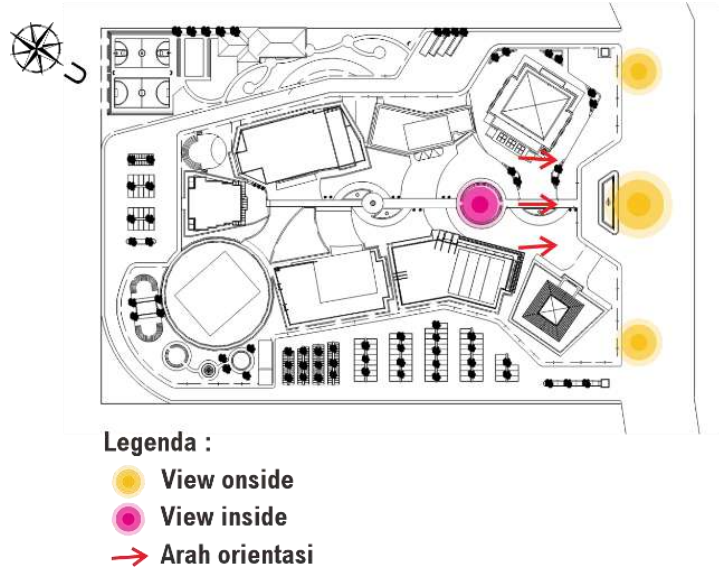

Gambar 18. Analisa Orientasi

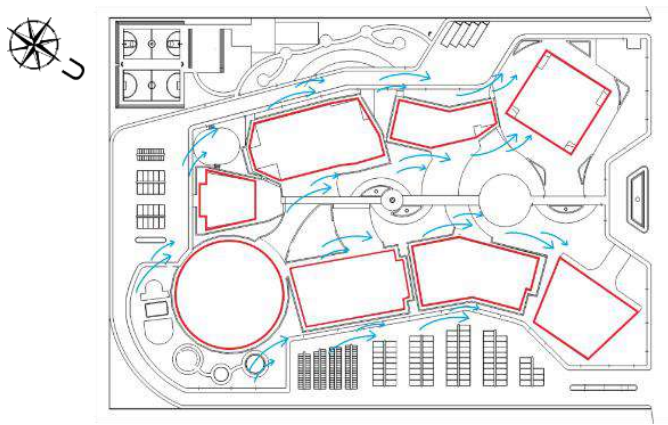

Gambar 19. Bentukan Massa

Bentukan massa terbentuk mengikuti arah angin, dan kemudian terbagi dari beberapa bentukan dari geometri campuran yaitu dari bentuk lingkaran, persegi,

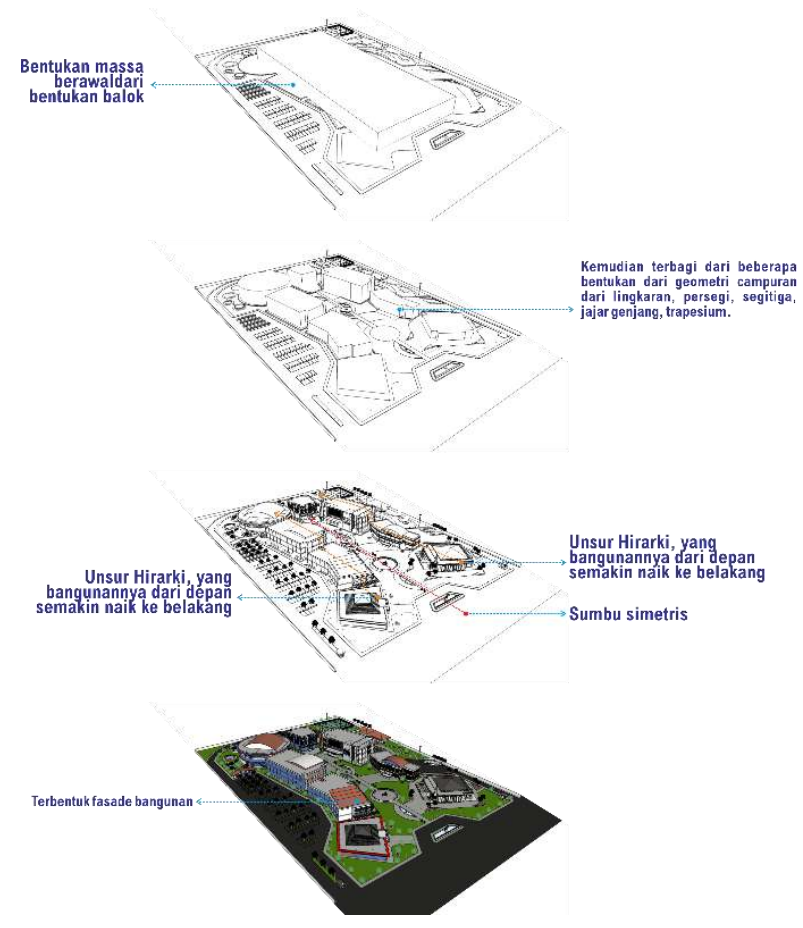

Gambar 20. Bentuk Konsep Gubahan Massa

\section{KESIMPULAN}

Sekolah Tinggi Arsitektur, Seni dan Desain dengan fungsi sebagai pusat pendidikan dan seni di Semarang merupakan fungsi utama dari bangunan yang akan dirancang nanti. Fungsi ini dijadikan tolak ukur untuk menentukan konsep visual bangunan agar mewujudkan citra visual bangunan itu sendiri.

Dalam perancangan bangunan ini diharapkan dapat menampilkan visual arsitektur yang diharapkan sesuai dengan fungsinya. Konsep yang akan digunakan dalam bangunan mengunakan pedekatan arsitektur post moden yang tujuan post modern adalah memberikan kesempatn pada bangunan untuk dapat di ekspresikan dalam berbagai bentuk. Yang pada fasade dan gubahan massa bangunan tersebut bebas berekspresi bentuk tak beraturan. 


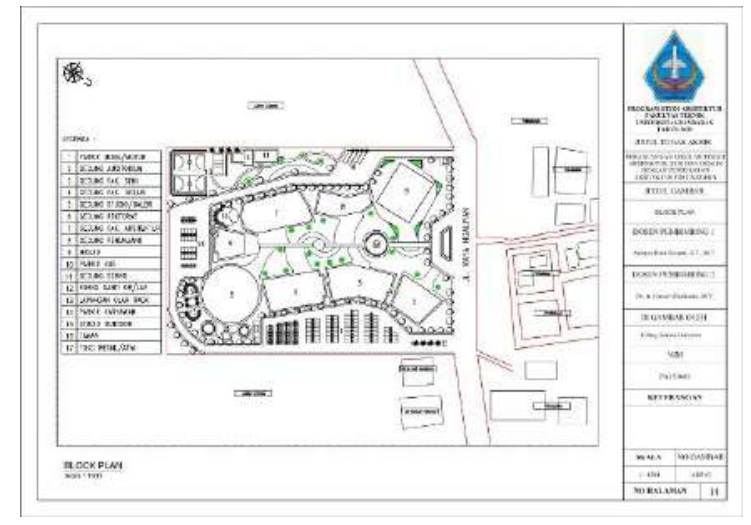

Gambar 21. Block Plan

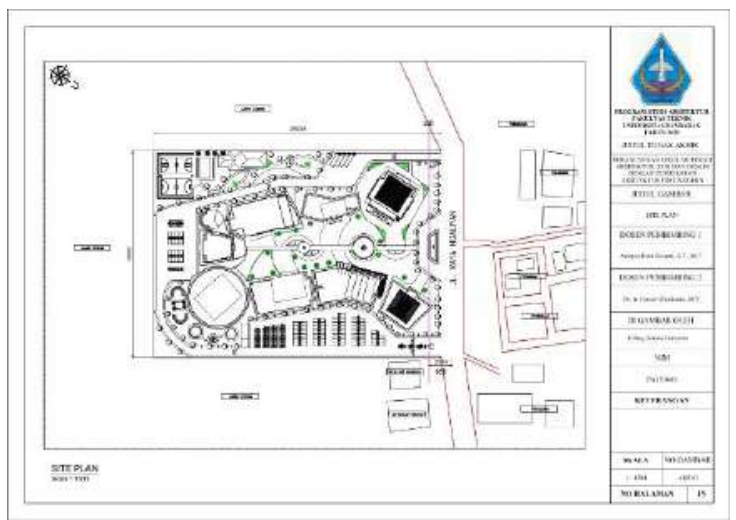

Gambar 22. Site Plan

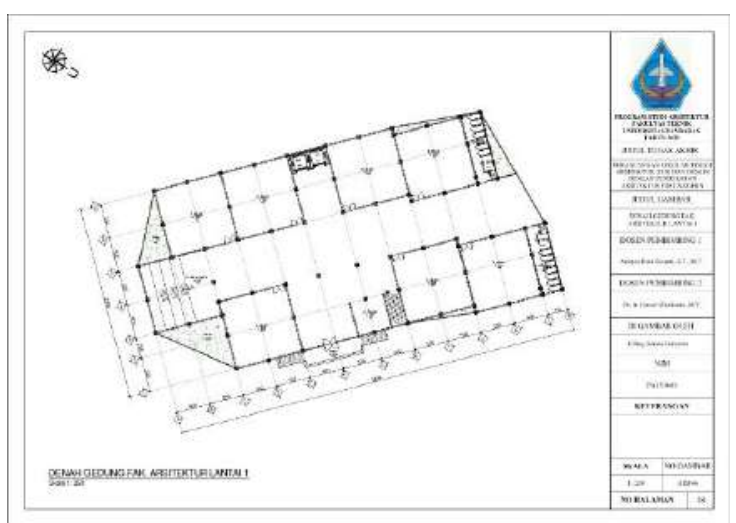

Gambar 23. Denah Gedung Fak. Arsitektur Lantai 1

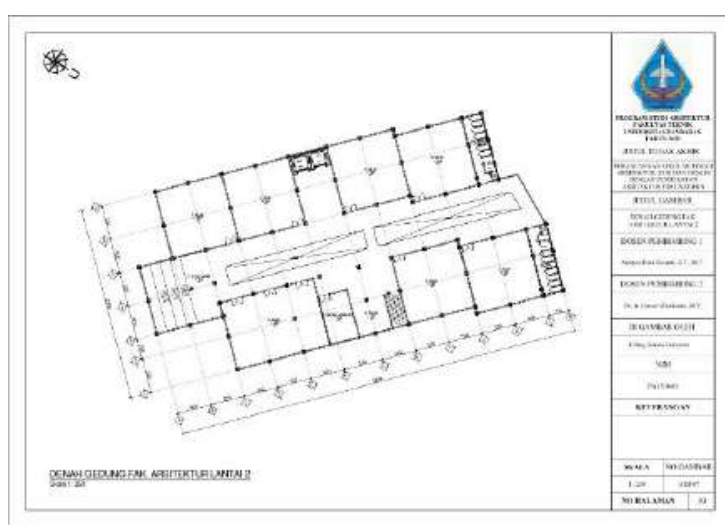

Gambar 24. Denah Gedung Fak. Arsitektur Lantai 2

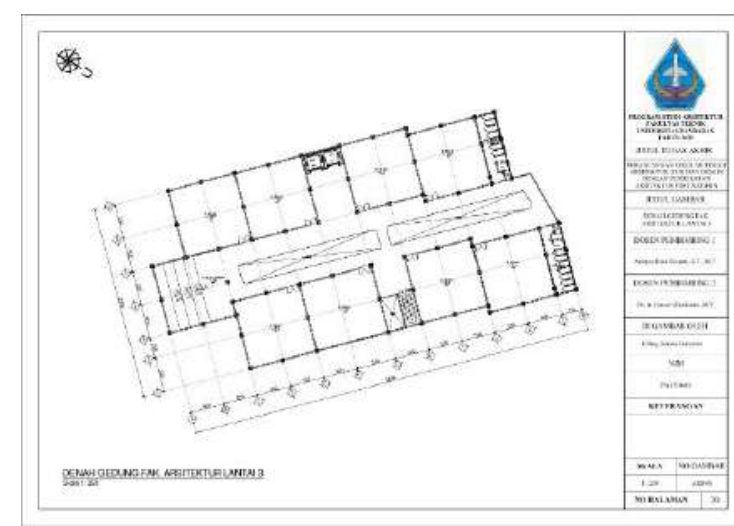

Gambar 25. Denah Gedung Fak. Arsitektur Lantai 3

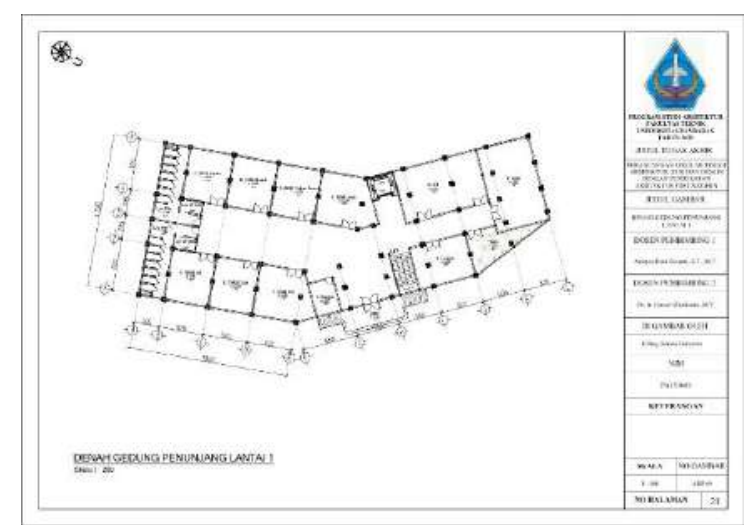

Gambar 26. Denah Gedung Penunjang Lantai 1 


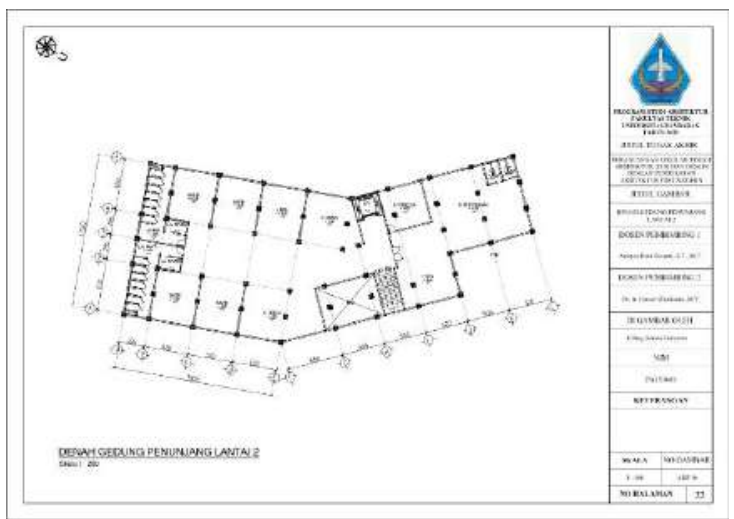

Gambar 27. Denah Gedung Penunjang Lantai 2

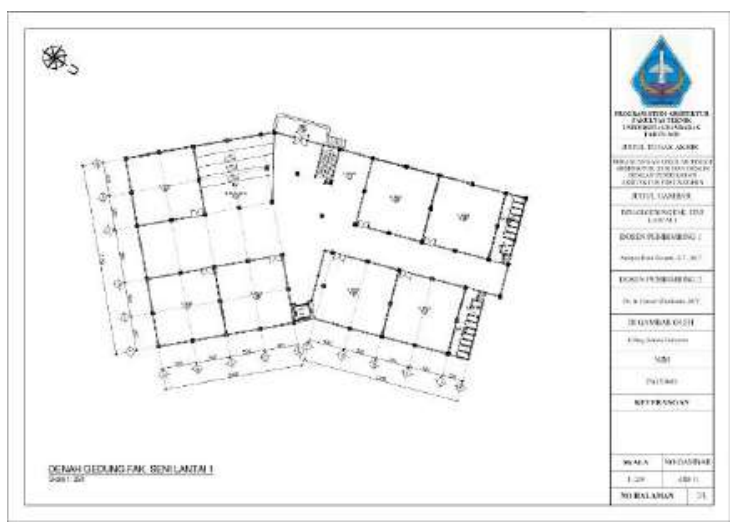

Gambar 28. Denah Gedung Fak. Seni Lantai 1

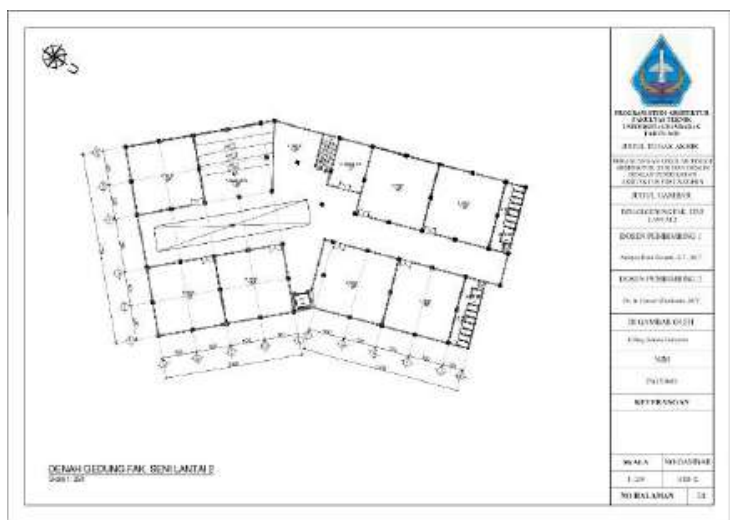

Gambar 29. Denah Gedung Fak. Seni Lantai 2

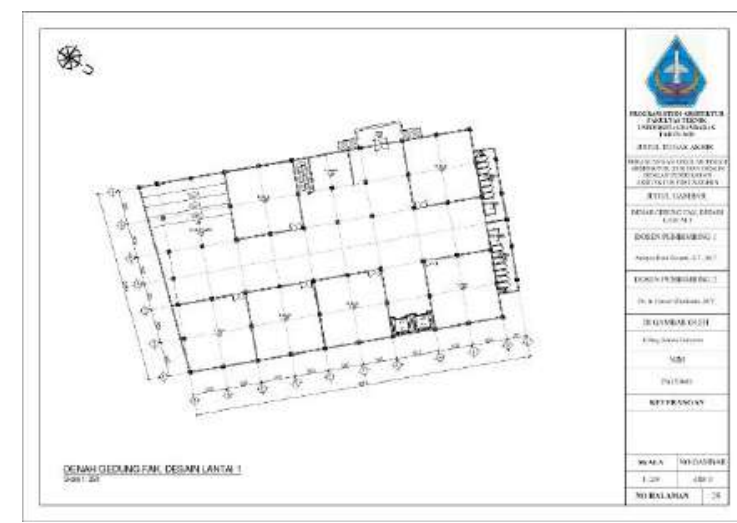

Gambar 30. Denah Gedung Fak. Desain Lantai 1

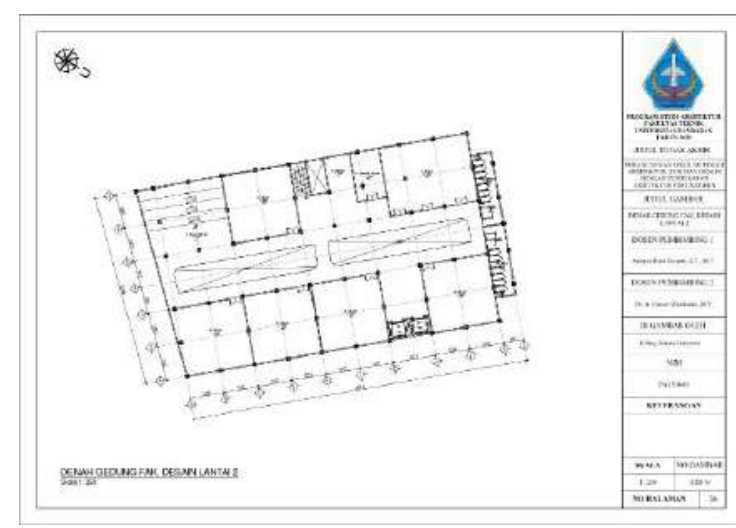

Gambar 31. Denah Gedung Fak. Desain Lantai 2

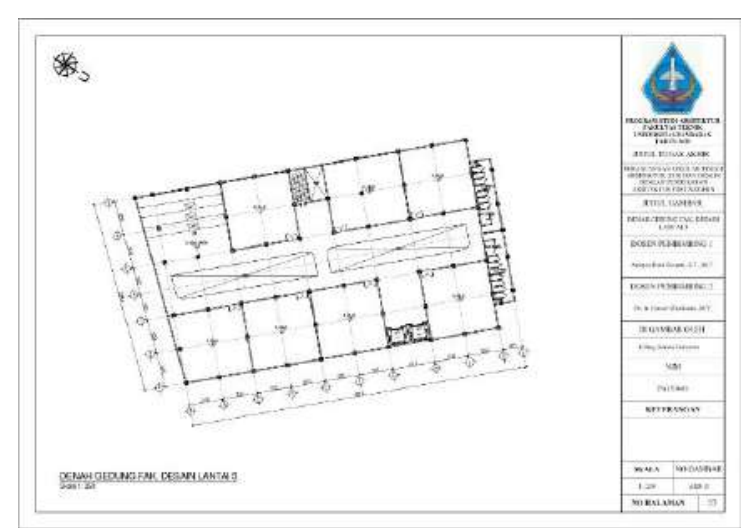

Gambar 32. Denah Gedung Fak. Desain Lantai 2 


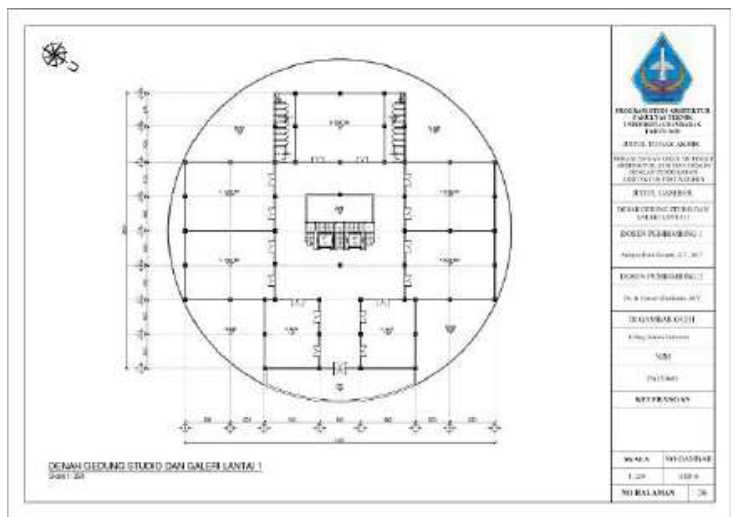

Gambar 33. Denah Gedung Studio Lantai 1

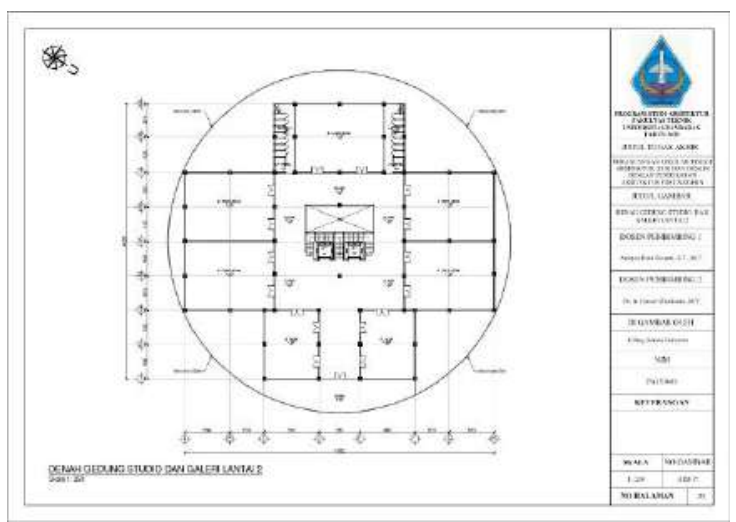

Gambar 34. Denah Gedung Studio Lantai 2

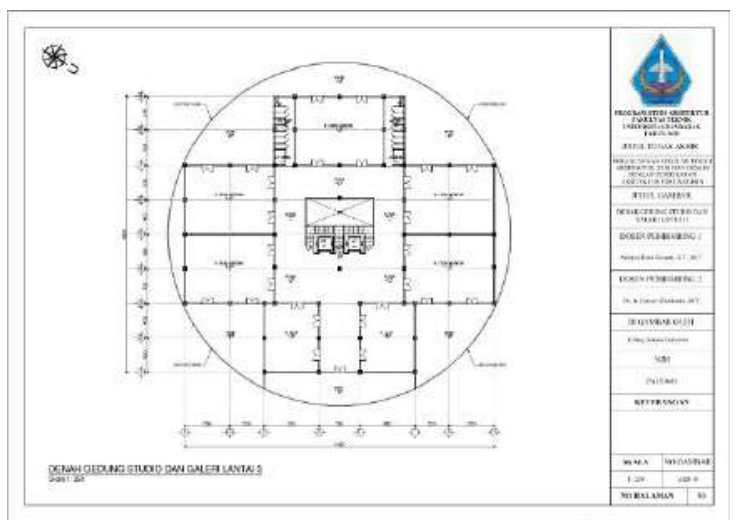

Gambar 35. Denah Gedung Studio Lantai 3

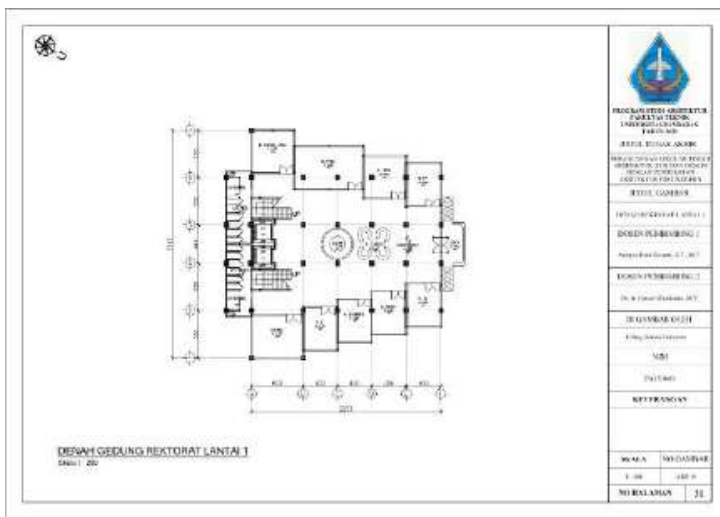

Gambar 36. Denah Gedung Rektor Lantai 1

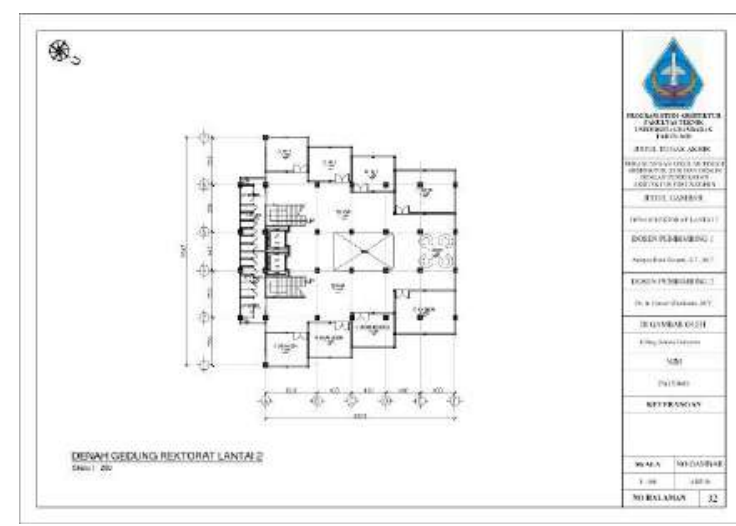

Gambar 37. Denah Gedung Rektor Lantai 2

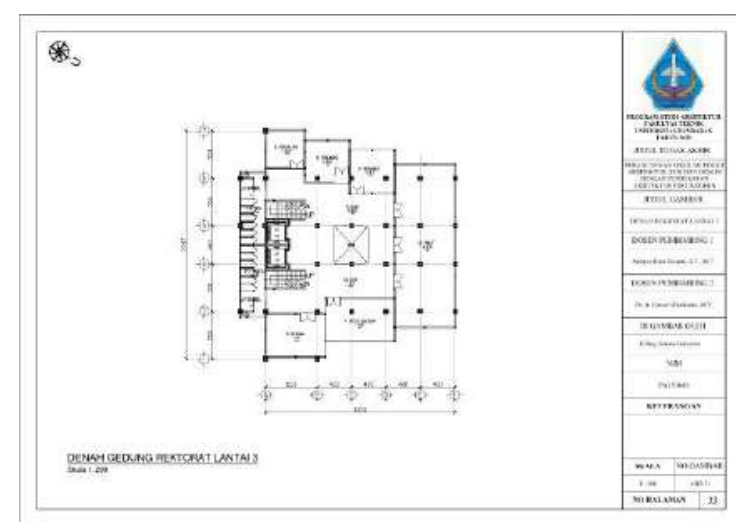

Gambar 38. Denah Gedung Rektor Lantai 3 


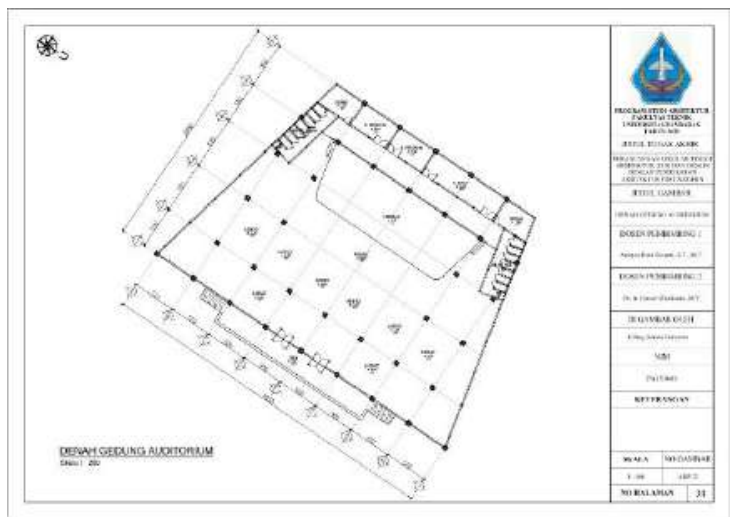

Gambar 39. Denah Gedung Auditorium

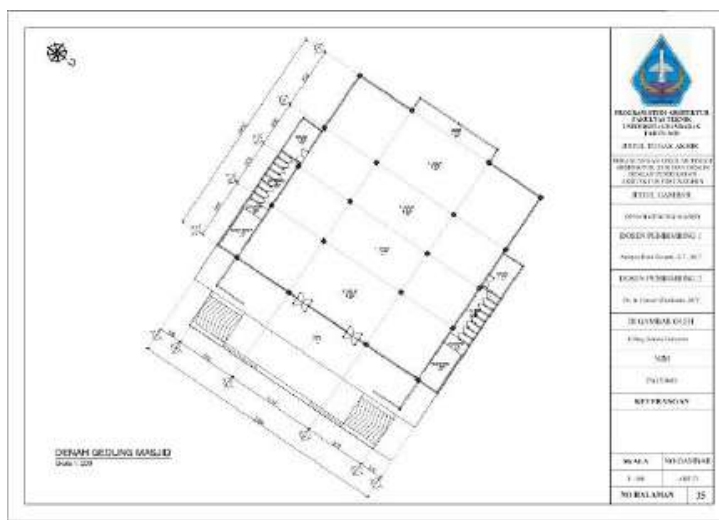

Gambar 40. Denah Gedung Masjid

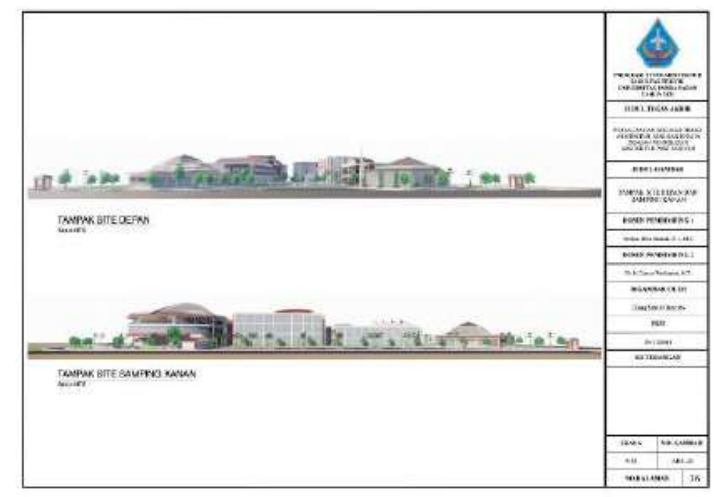

Gambar 41. Tampak Depan dan Tampak Samping Kiri Site

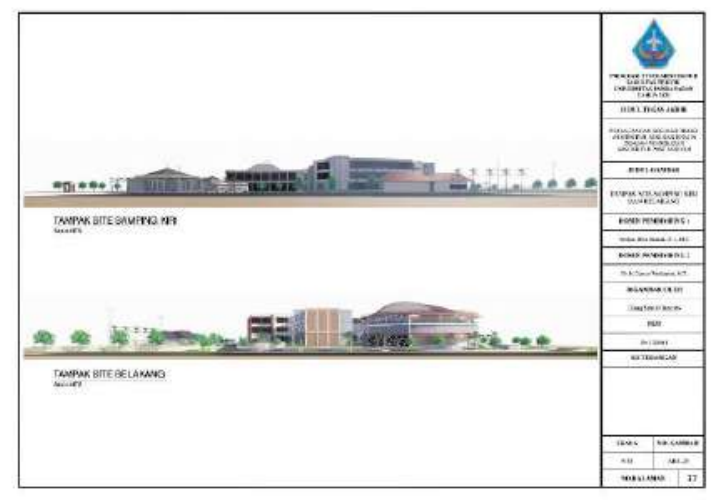

Gambar 42. Tampak Samping Kanan dan Tampak Belakang Site

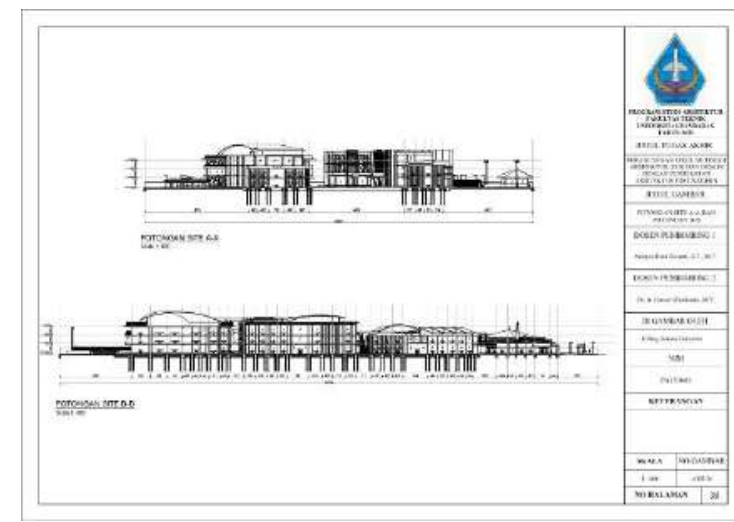

Gambar 43. Potongan A-A dan Potongan B-B Site

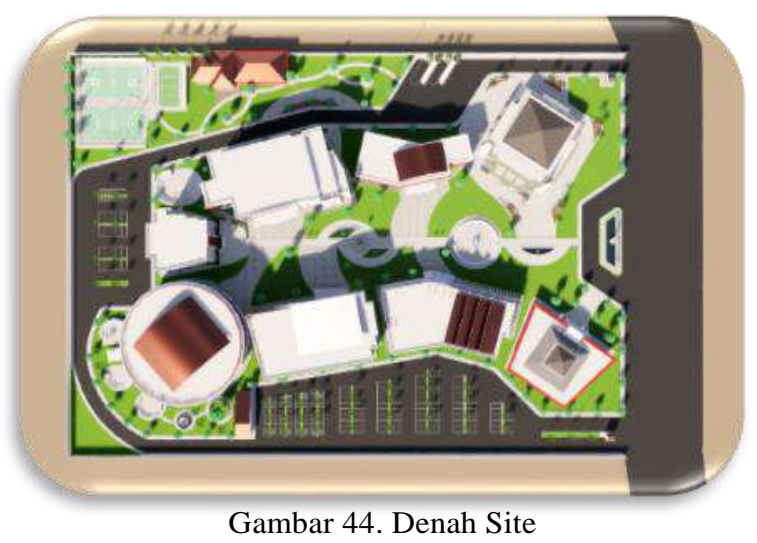




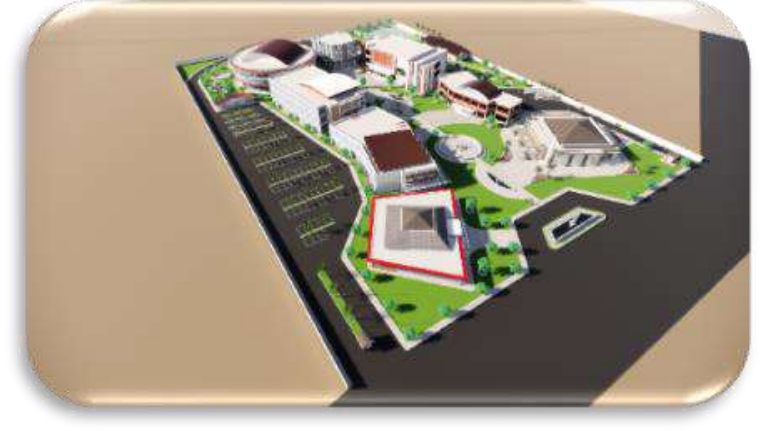

Gambar 45. Perspektif Eye Bird

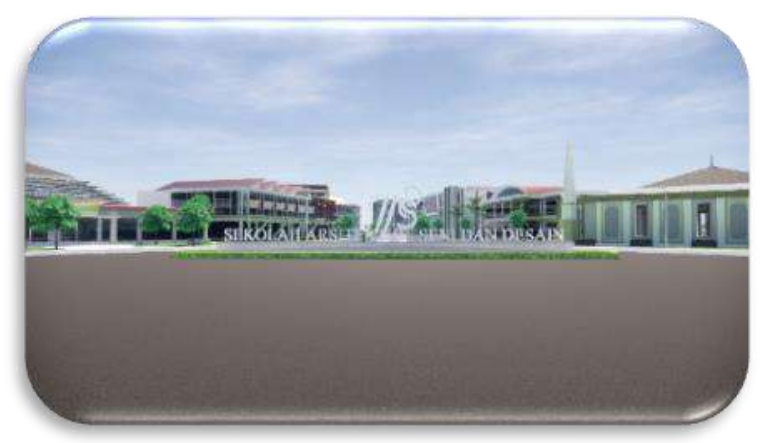

Gambar 46. Perspektif Eksterior

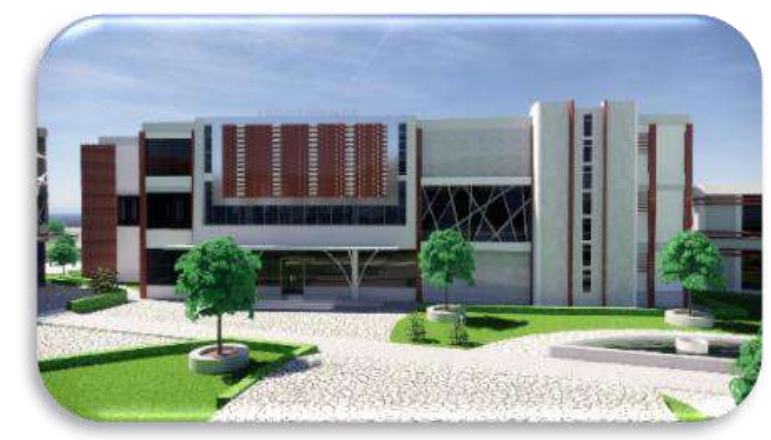

Gambar 47. Perspektif Eksterior Gedung Fak. Arsitektur

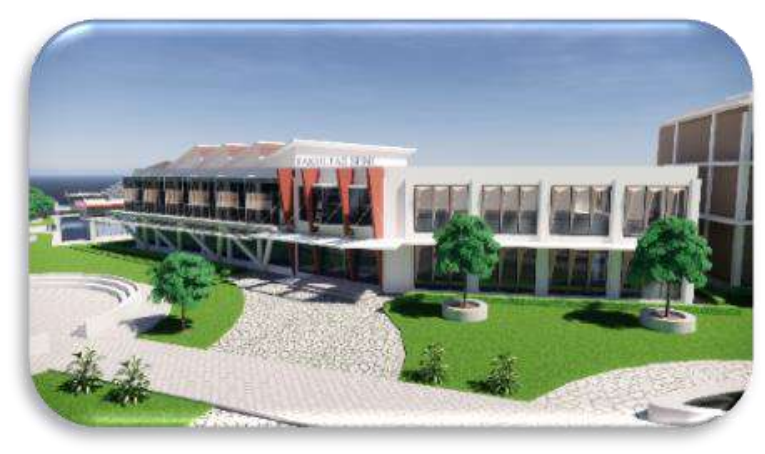

Gambar 48. Perspektif Eksterior Gedung Fak. Seni

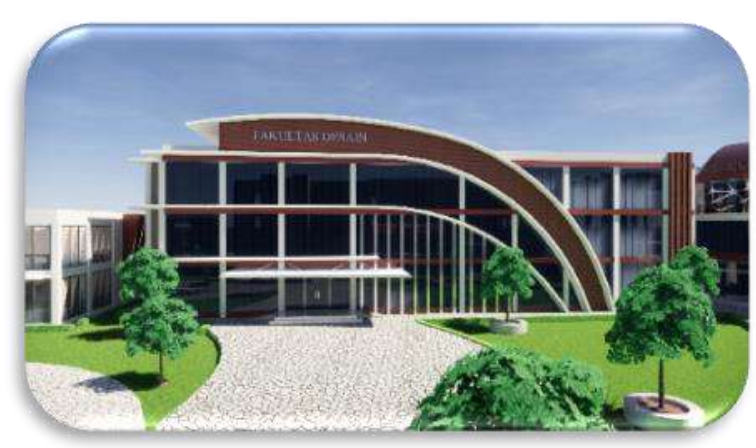

Gambar 49. Perspektif Eksterior Gedung Fak. Desain

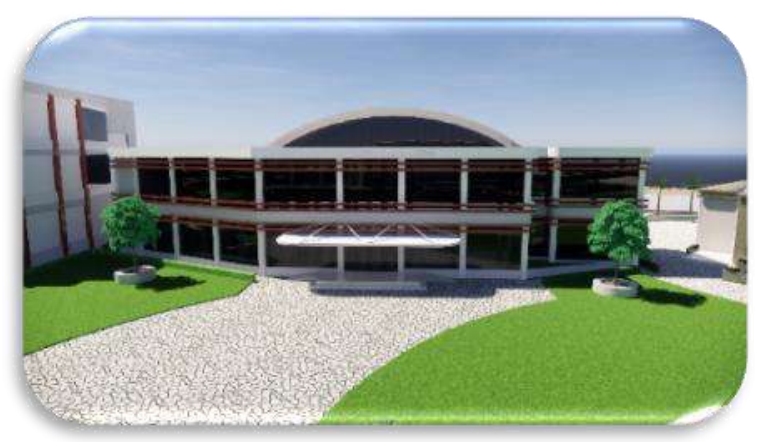

Gambar 50. Perspektif Eksterior Gedung Penunjang

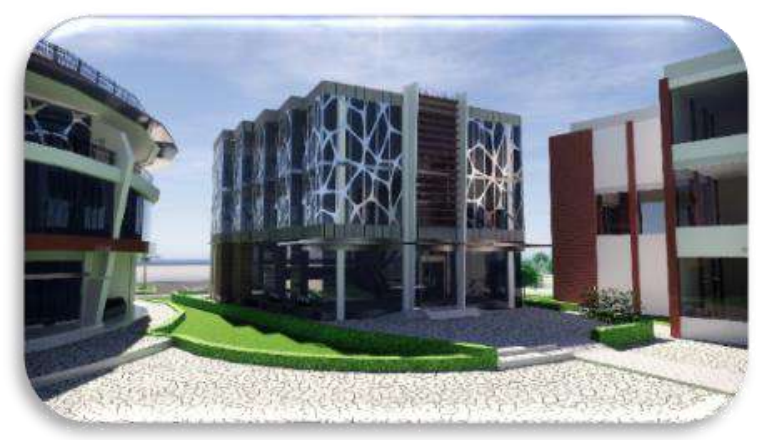

Gambar 51. Perspektif Eksterior Gedung Rektorat

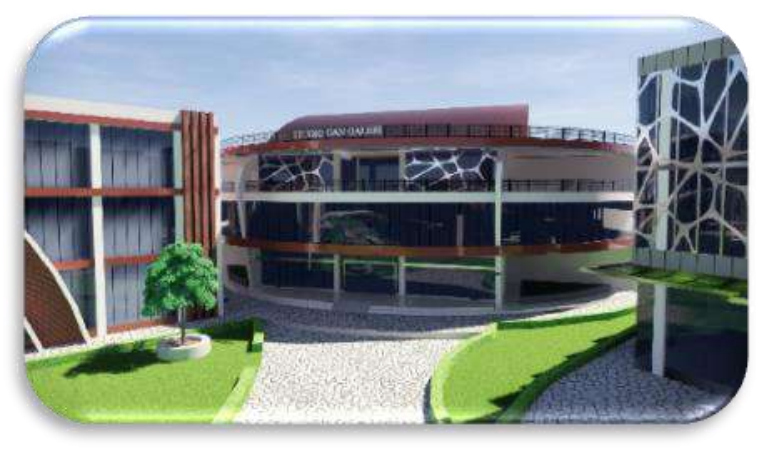

Gambar 52. Perspektif Eksterior Gedung Studio dan Galeri 


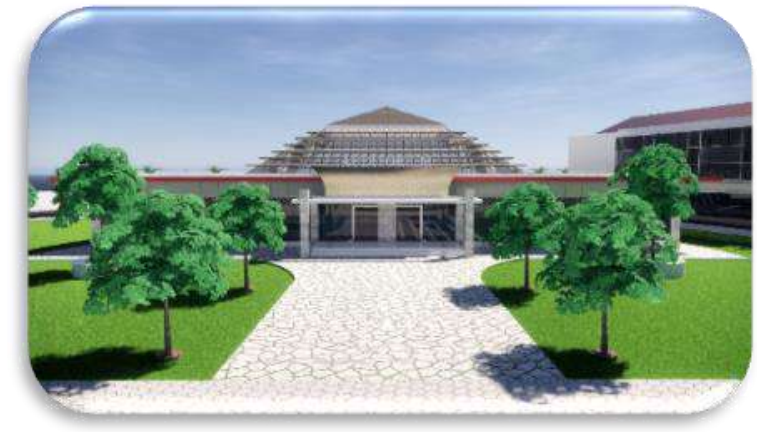

Gambar 53. Perspektif Eksterior Gedung Auditorium

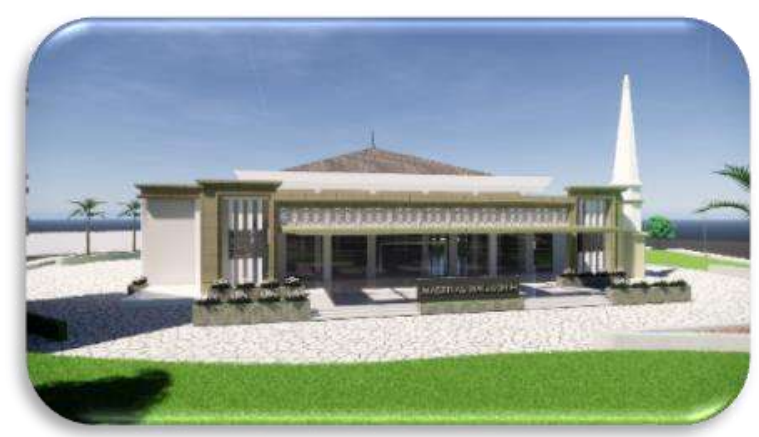

Gambar 54. Perspektif Eksterior Gedung Masjid

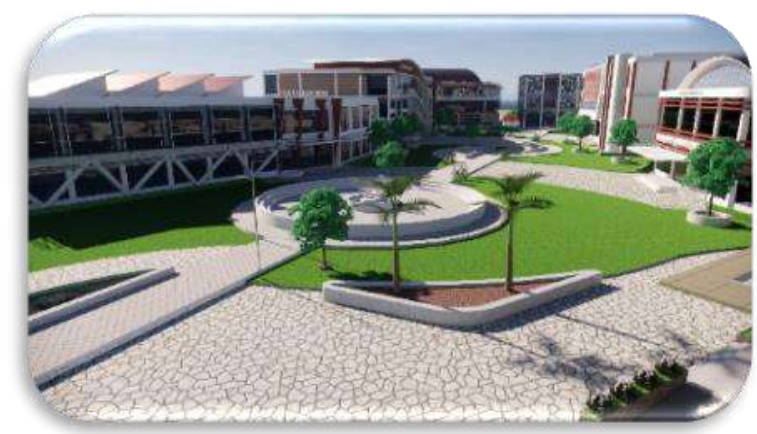

Gambar 55. Perspektif Eksterior Open Space

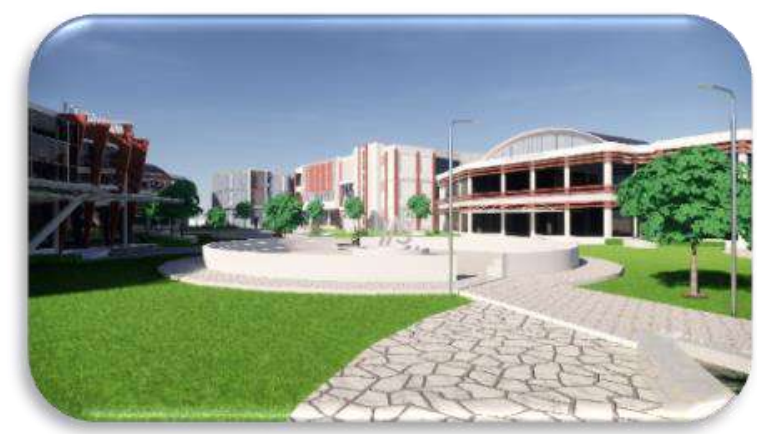

Gambar 56. Perspektif Eksterior Open Space

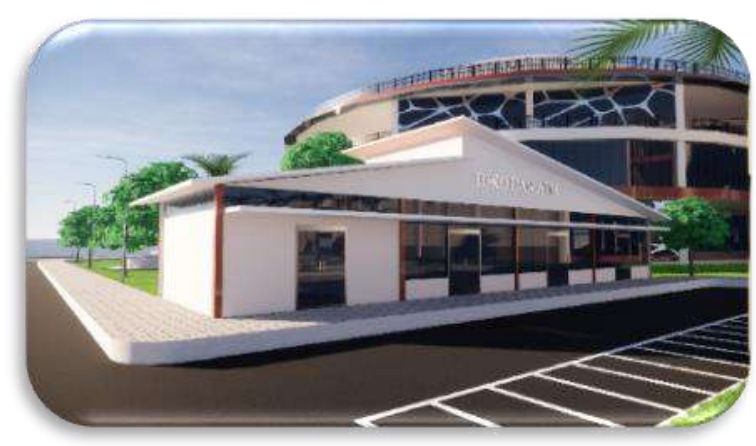

Gambar 57. Perspektif Eksterior Toko dan ATM

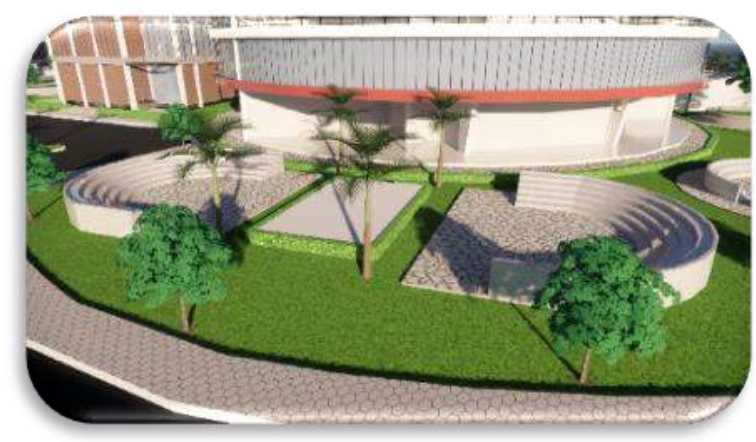

Gambar 58. Perspektif Eksterior Studio Outdoor

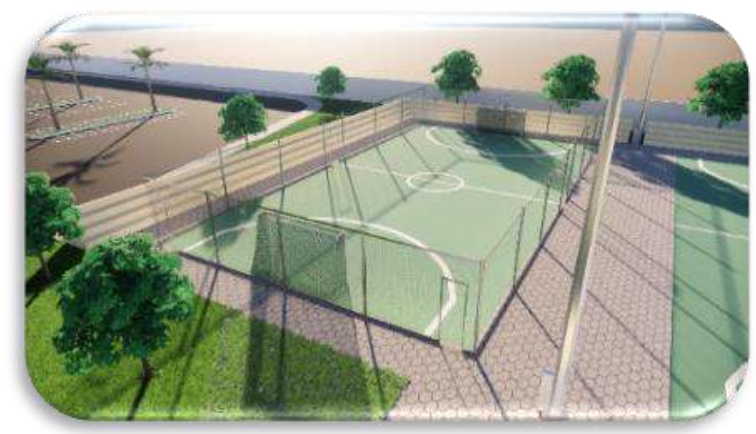

Gambar 59. Perspektif Eksterior Lapangan Futsal

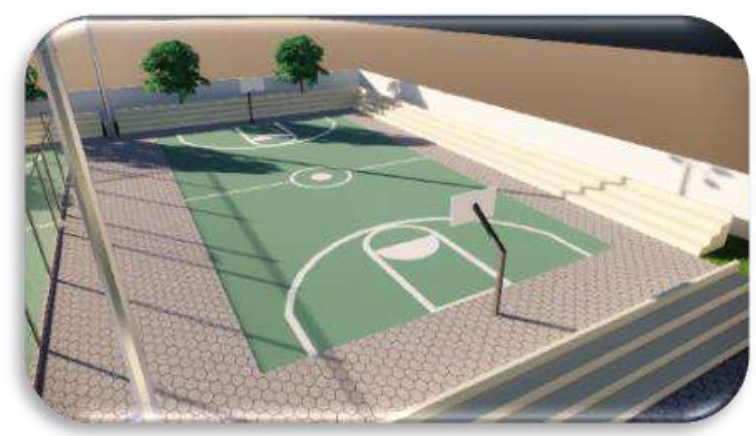

Gambar 60. Perspektif Eksterior Lapangan Basket 


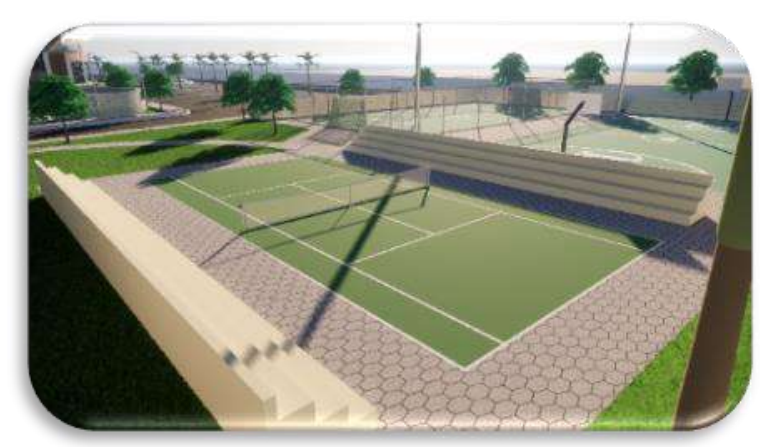

Gambar 61. Perspektif Eksterior Lapangan Badminton

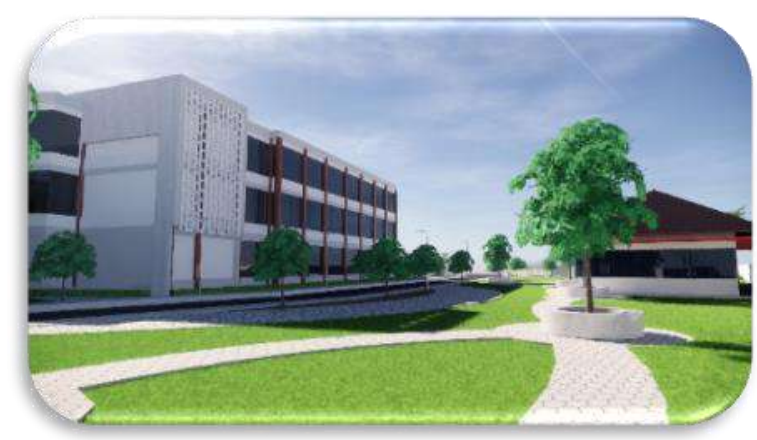

Gambar 62. Perspektif Eksterior Open Space

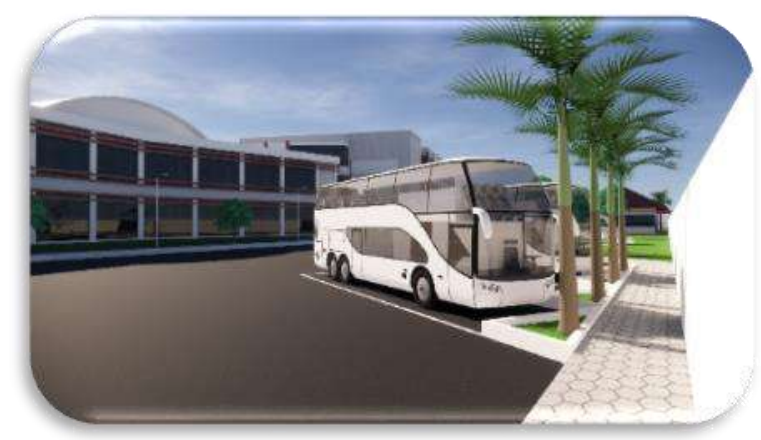

Gambar 63. Perspektif Eksterior Parkiran Bus

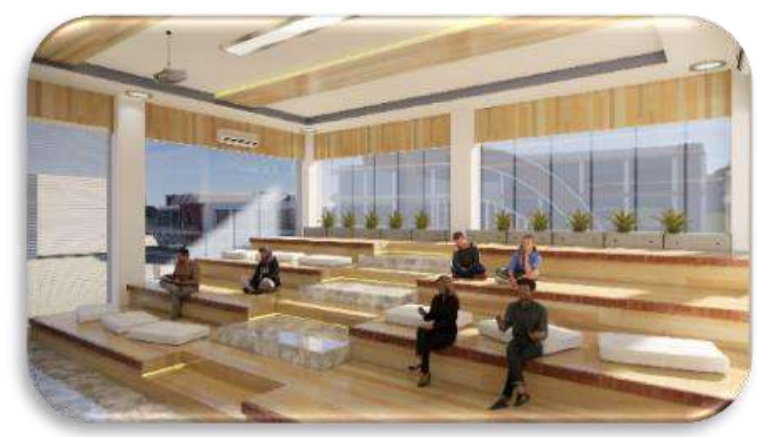

Gambar 64. Perspektif Interior Non Formal

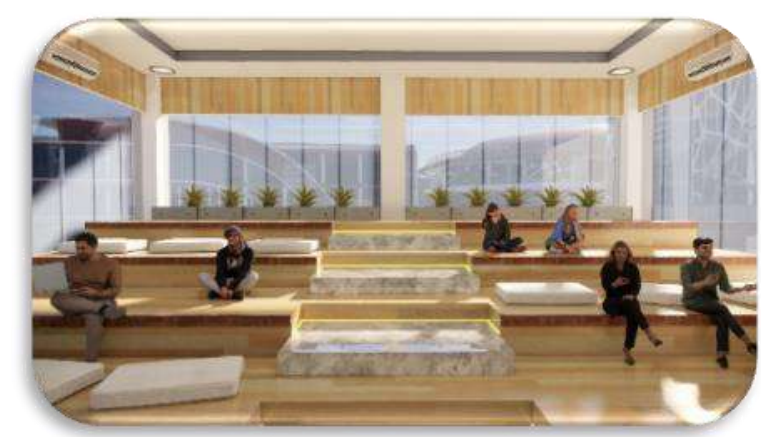

Gambar 65. Perspektif Interior Kelas Non Formal

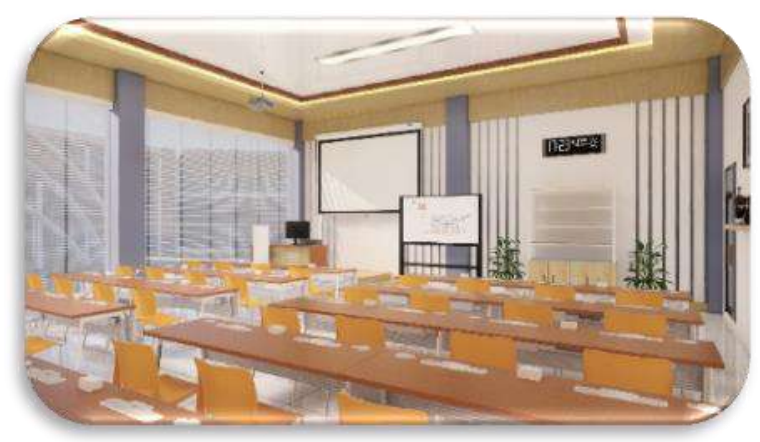

Gambar 66. Perspektif Interior Kelas Formal

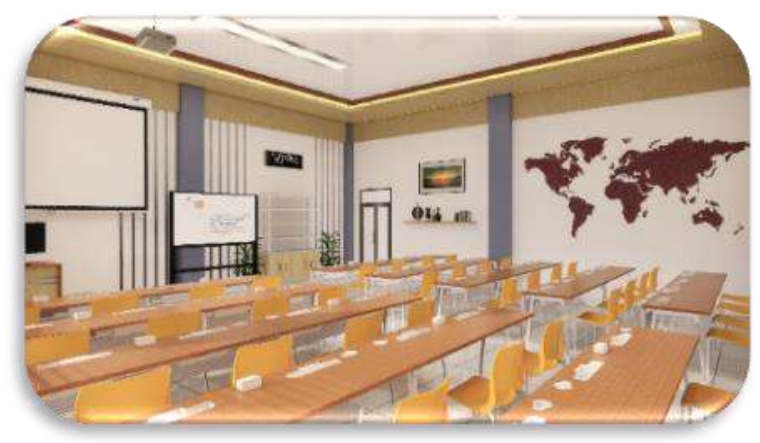

Gambar 67. Perspektif Interior Kelas Formal

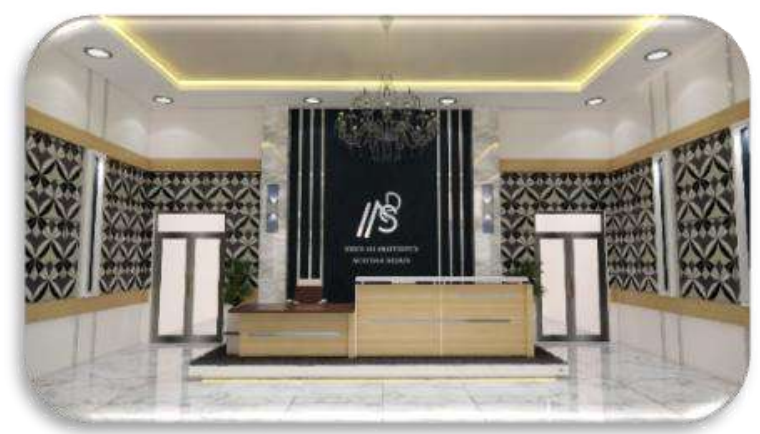

Gambar 68. Perspektif Interior Recepsionist 


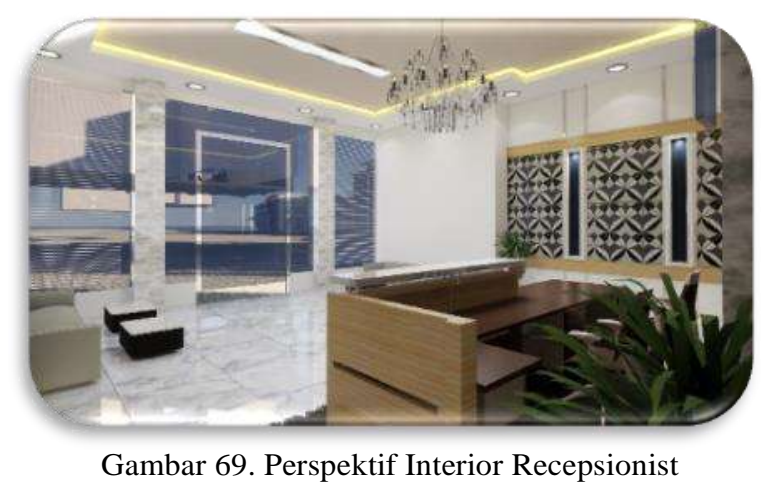

\section{DAFTAR PUSTAKA}

Nirbhawa. Marendra Mukti. 2017. Jurnal Perancangan Interior Gedung PSDI Institut Seni Indonesia Yogyakarta

Ching, Francis D.K. Arsitektur Bentuk, Ruang, dan Tananan. Jakarta. Penerbit Erlangga

Neufert, Ernst. Terjemahan oleh Dr. Ing Sunarto Tjahjadi, jilid 1, Data Arsitek. Jakarta. Erlangga

Neufert, Ernst. Terjemahan oleh Dr. Ing Sunarto Tjahjadi, dan Ferryanto Chaidir, jilid 2, Data Arsitek. Jakarta. Erlangga Lippsmeiner, George. 1994. Bangunan Tropis. Jakarta : Erlangga

Standarisasi Nasional Indonesia SNI 03-65722001

Peraturan Daerah Kota Semarang Tentang RTRW No. 14 Tahun 2011

Peraturan Kementrian Pendidikan dan Kebudayaan

Badan Nasional Standarisasi Pendidikan www.archdaily.com https://arthaventd1.wordpress.com/bauhaus/ https://ars2016matana.wixsite.com/website/sin gle-post/2017/12/17/BAUHAUS

https://www.google.co.id/maps/place/Bauhaus + Dessau

https://www.isi.ac.id

https://id.wikipedia.org/wiki/Institut_Seni_Ind onesia_Yogyakarta

https://www.google.com/maps/place/Institut+S eni+Indonesia+Yogyakarta

https://www.facebook.com/interiorisijogja/pho tos

https://www.google.com/maps

https://bsnp-indonesia.org/standar-sarana-danprasarana/ 